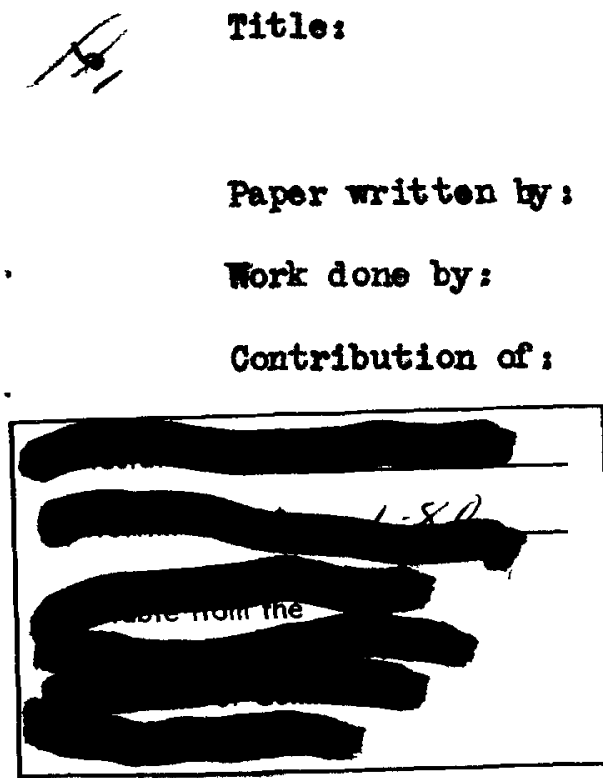

-DEVELOPMSM OF A FURNACE FOR METIIHG

AND CASTING URANIUM METAL.

- Bobert J. uni cetti

- Robert J. Anioetti

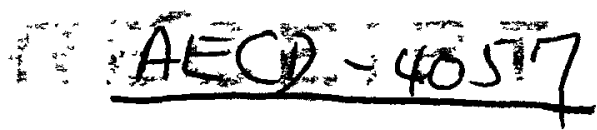

- Massachusetts Institute of Teohnology.

Cambridgo, Masachusetts, and Yatal

Eydrides Inoerporated, Beverly,

Mas sachusetts.

I. IMR RODUCTION

At the start of the uranium project, 11 t

necessary to design and contruot a farnace suitable for molting and oasting uranium powder into masive form. Early experiments showed that pressed and sintered compacts of uraniun powder irere Inforior to thoccast motal. Since the motal powder is quite phrophoric, such ossting would have to be done in an inert atmonphore or in vacum. Prolimimry investigations indicated that the porder could be melted in vacuum induoti on furnoce. Faoilitios were then ongaged in the Dopartment of Motallurgy at the Hassachusotts Instituto of Toohnolog for dereloping a vacuum induoti on furmace to melt and cast uranium on a large doale.

\title{
II. DISCUSSION
}

Barly in 1942, a fund was oreated at the kassachusetts Institute of Toohnology to einance the development work on motal casting. For this purpose, the ahell of an old fur nace preflously described by J. C. Chlpman in Iranseotions of the merican Institute of lining and Wotallurgieal Enginoers, for 1940 wes used. Thi : furna conof sted essentially of a voun-tight sholl onolasing an induotion coll and a oruoiblo indide this 0011 to be" used for mofiting

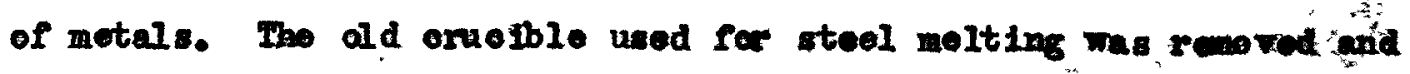

This documino is ch RELEASADLE rutoretn gircial Date: $4-7-11$ 


\section{DISCLAIMER}

This report was prepared as an account of work sponsored by an agency of the United States Government. Neither the United States Government nor any agency Thereof, nor any of their employees, makes any warranty, express or implied, or assumes any legal liability or responsibility for the accuracy, completeness, or usefulness of any information, apparatus, product, or process disclosed, or represents that its use would not infringe privately owned rights. Reference herein to any specific commercial product, process, or service by trade name, trademark, manufacturer, or otherwise does not necessarily constitute or imply its endorsement, recommendation, or favoring by the United States Government or any agency thereof. The views and opinions of authors expressed herein do not necessarily state or reflect those of the United States Government or any agency thereof. 


\section{DISCLAIMER}

Portions of this document may be illegible in electronic image products. Images are produced from the best available original document. 
replaced with a graphite orroible, Fith in the coll a fusod silica tube lined with $\mathrm{K}-30$ insulating bricks insulated the cruoible from the coil. A remorable watermoooled copper dome with sight glass fitted on the outer eylinder. The unit was firmly bolted to the bottom plate of a standard Ajax-Horthrup furnace frame so the furnace could be tilted and a heat poured into a vacuum thight mold attached to the domed cover.

Preliminary heats were in alundum cruatbles surrounded by a graphite shield with no attempt made to cast the motal. The powder melted down into sound ingot topped with an oxide crust. There was little or no attack upon the oruolble by the molten metal, and pressures in the order of $500-3000$ miorong were attained. Sereral heats were poured into a graphite mold by tilting the furnace. Bosults rere not too satisfactory since the motal tended to solidify on the cruoible lip and the rate of pour could not be too well controlled. Cold shuts were present on the casting. The furmoe was then modified so that the motal could be bottom poured into a mold. This inoluded the following elementss

1. A bawe made of $\mathrm{K}-28$ insulating briak

2. A fus od silica tube which fitted loosely inside the incuotor coll.

3. I craphite mold resting on the $\mathrm{K}-28$ brick and surrounded by briok of the same material.

4. The apport made of insulating briak and of alundum brick resting on the mold and designed to support the crucible. These pieces contained a hole through wioh the motal flowed from the eruosble into the mold.

5. A graphite oruoible resting on the alumina brick wich serred as the boating element.

6. In al umina oruotble in the the graphite crualble.

7. A stopper rod made of an alundum tube whioh olosed the hole in the bottom of the alumina cructible and extended upwird to a holo in the graphite cover.

8. A steel rod attached to the alundu tabe and oxtonil is arough tho furmose cover.

9. A vacuum weal in the furmos vever through which the stoel rod extended. For this purpose, the somenlied IIson soul mis used. 


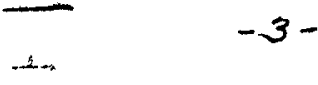

The entire furnace mas eracuated down to a fer millimeters of meroury. The eruotble was heated by high frequency current applied to the induction coil and a fter the charge had melted, the stopper rod was raised thus allowing the molten motal to flow from the orucible into the mold. This method produced sound castings with good surfaco.

Deaign work which had started on a production furnace - Imilar to that of the rationa 1 Bureau of Standards was discontimed In favor of a bottom pour furmace. The first unit construoted was essentialiy an expanded model of the experimental furnece and was capable of holding an $8^{n}$ diameter crucible. A removable bot tom plate onabled one to lower this plate and remove the cast ingot. hruer ous oastings were suocesstully made with this furnace.

The next stop in derelopment led to the construction of a fused silica tube furmace and the use of graphite crucibles. $\Lambda$ number of small moits had beon made at the Oniversity of Ohioago in graphite oruoibles with no adverse effeot upon the motal though a literature survey had pointed to the formation of a carbide. A 12" I.D. Fused silica tube 86" long was placed inside an induotion coll and set upon a water-cooled furnace base with removablo bottom-plate to permit lowering of the casting from the bottom. Provisions were made in the mer-cooled top oorer plate for a vaounm tight seal and sight glass. A graphite stopper rod repleced the alundum rod, and K-30 inoulating brioks wore used as furmoce lining.

Early in January 1948 the foundry constructed at Metal Fydrides Incorporated was ready to go into produotion and casting operations were transferred to that place. Sinoe that tim a muber of improveunts more made upon the original furnaces and operating technique. 


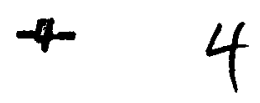

A new type furnace base was dereloped with a selflooking bottom plate oliminating the use of a bolted on plate. Insulation was reduced wo that a larger oruotble could be acoommodated.

Casting yields from uranium parder were about $85 \%$ in an effort to inorease the yield varying amount of calcium hydride were added to the powder with the expectetion of reducing the oxdie flim formed on the surface of each partiole, and thus decrease the "hold-up" effect of the axide upon the motel. There was no definite improvement upon casting yleld but one beneficial result was noted. The boron impurity was in many cases lowered.

It was notod that oasting yiolds did not vary greatly with pressures from 500 microns to 3000 miarons.' Fith lower pressures of about 60 miorons ylelds tended to increase. Later work by Nallinokrodt Company confirmed this observation. However, waoums of thi s order were difficult to maintain without excessive maintenance work. In an attempt to prevent oxidation a series of heats were made in an atmosphere of argon and of helium. There ws no apparent increase in yield and the surfaces of the billet were pporer. Billets cast in helium were more pitted and had a generally poorer surface than billets cast in argon. Billet tops were swelled and porous. Commeraial grades of argon and helium wore used and nitrogen, present as an impurity, may have been the mafor factor in producing the poor sur faces. Horever, in view of the faot that billets cast in helium wore worse than those cast in argon, it was believed that holium was soluble to 8 cane extent in the molten motal. 
$-5$

In cruoible manufaoture a method was devised whereby a center core was out from the graphite cylinder leaving a sleeve which formed the walls of the crucible. A plug was then tightly fitted into ane end to form the finished oruoible. The conter core was of such size that a mold for billets could be machined from it.

On a number of occasions the stopper rod beoame comontted to the crucible or broke so that the metal could not be poured. To eliminate such efficultios a $3 / 4$ inoh hole was drilled in the bottom oenter of the orucible and plugged with a short graphite rod. Thenever a heat oould not be cast in the nomal menner the furmoos was filled with argon, the cover plate romored, and the emergen

- plug pushed out with a long graphite rod. The plug always floated to the top of the billet.

Operating schedules were arranged so that a heat could be made every half hour. The orucible side wall temperatures was brought rapidly to $1550-1600^{\circ} \mathrm{C}$ and matained there until a metal temperature of $1400-14600 \mathrm{C}$ (optical pyrometer) was reached. At firat crucible life was shortenod but by raising the aruoible bottom 1" $-2^{\prime \prime}$ above the bottom of the induotion coll no more oracking of erucibles was experienced. Contray to the experienoe of others best oaxting yields were obtained with apouring temperature of 1400 1450 $\mathrm{C}$. Temperatures of $1500^{\circ} \mathrm{C}$ were found to be best when reositing ho els from extruded billets. Casting jields from rejooted rods and oggs averaged $97 \%$, whereas yleld from heols varied from $82 \%$ to $90 \%$ depending upon the surfuce oxidation of the metal.

A number of billets were out to determin if any internal pipes were present. No billets wore found to contain such internal roids. The orucible was intentianally sot on the mold so that the 


\section{-6- 6}

metal after pouring cam to about $1^{n}$ from the bottom of the crucible. In this manner good hot-top was minteined and littlo or no piping oocurred. Billets four or more inahes from the bottom of the crue iblo all had fairly long pipes.

At the se high operating temperatures, there was considerable sticking and pitting of the graphite mold. Several washes of zorconia, zinc oxide, alumina, and $\mathrm{U}_{3} \mathrm{O}_{8}$ were tried. Of these a thick slurry of $\mathrm{O}_{3} \mathrm{O}_{8}$ minus 100 mash suspended in carbon tetrachlorid was found to be best. Reoently a high temperature "Zirconite" mold wash consisting of zircon sand and clay was very suocessful. The was can be easily applied with a brush and air sets quickly to a hard surface. Mold life was considerably longthened and surfeco appearance of the billets greatly improved.

III. SURMARY

Design and development over a period of neveral years of a furnace for casting uranium motal led to the present type furneoe shown in Fig. I.

The use of calcium hydride to increase casting yield was not successful but boron content was lowered through use of the hydirido

Nolting in an atmosphere of argon or of hellum did not prove to be superior to vacuum casting. 
17

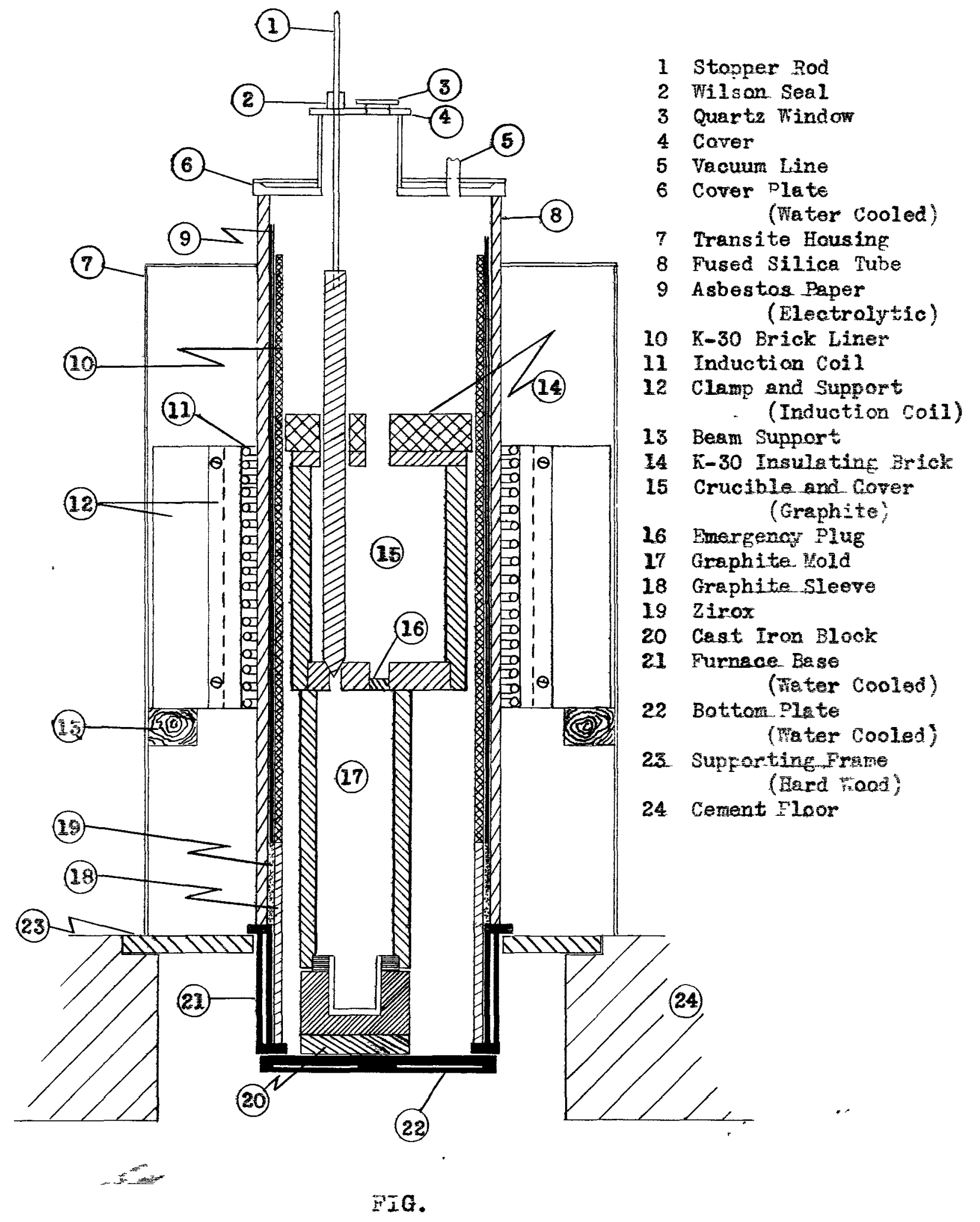

WIELVE INCE QUARTZ TUBE FURNACE

$$
\text { รอง } 10:-1 / 8^{n}=1^{n}
$$$$
\therefore 800
$$ 